\title{
Unforeseen Mentor
}

\author{
Eduardo Constantino ${ }^{1}$ (D)
}

Received: 3 March 2021 / Accepted: 28 June 2021 / Published online: 27 August 2021

(C) Academic Psychiatry 2021

Mr. Lee (a pseudonym with details disguised) greeted me even before I entered his hospital room, claiming as always that he could recognize my rapid footsteps. He was almost blind, but he could still see colors and vague shapes. Tragically, he was progressively losing even this remaining vision. I had been treating Mr. Lee for five weeks and over that time, we had settled into a routine: I would see him last before morning rounds, lingering to discuss current events or the arts. He was a playwright in his late 30 s and although modest himself, I had found out from his partner Mario that he had received much acclaim for several off-Broadway shows. I was sure that Mr. Lee's worsening blindness must have been devastating, but he never complained and instead maintained a calm and hopeful outlook. Mario described him as "zen-like," an appropriate description as I found our talks each morning the most tranquil part of my day.

My beeper went off as I stepped out of his room, yanking me back to the grim reality of life as a medical intern in a New York City hospital where I found myself at the epicenter of the AIDS epidemic. Although HIV had been identified six years earlier in 1984, the hospital was now overloaded with patients suffering from its varied forms of devastation. We had started this new decade of the 1990s without any way to stop or even slow down the virus' progress. In the five months since graduating medical school, I was dealing with infections that had previously been so rare, that they often didn't appear in my textbooks. Mr. Lee's CMV retinitis was a perfect example. It had previously afflicted only the elderly and those undergoing chemotherapy, but we were now seeing it in younger patients with AIDS. And as with Mr. Lee, we often found that our treatments offered little help.

Later that day, I ran into Mario in the cafeteria getting coffee for several of their visiting friends. He was a devoted partner who took good care of Mr. Lee and he had been

Eduardo Constantino

eduardo.constantino@stonybrookmedicine.edu

1 Stony Brook University, Stony Brook, NY, USA fortunate not to have been infected himself. They had been a couple for a long time and they were used to the comments about their increasingly contrasting physiques. Whereas Mr. Lee was slightly built and getting thinner, Mario was much taller and bigger, with the sculpted body of a professional dancer. More revealing than his reserved partner, it was Mario who had told me how they'd met almost 10 years earlier when he had tried out and been rejected for a part in one of Mr. Lee's plays. He was also the one who expressed the couple's fear and worry. We spoke briefly, but I could see the stress of the previous weeks on his strained face and hear it in his choked voice.

Just before midnight, I got a page from Mr. Lee's floor-he had spiked a fever. Ten minutes later and I would have been home, but I was still on call. He frequently had fevers, mostly isolated spikes, but each fever needed an evaluation and a blood draw. Unlike many patients in the hospital, Mr. Lee had intact veins which made my job that much easier-a good thing at this hour. I stuck his arm, but I "blew" the vein, cursing to myself as I withdrew the needle.

"One more stick," I said preparing a new needle. This time I hit the vein perfectly and I hoped to still make it home in time to get six hours of sleep. I leaned onto the bed to check my watch and that's when I felt a sharp stab. The previous needle which I had forgotten to throw out was now sticking out of my left forearm. I could see that there was blood left in the attached tubing-Mr. Lee's blood. He couldn't see me pulling out the needle and squeezing the puncture site.

"Thank you, doctor," he said closing his eyes and settling back to sleep. "Hope you get some rest."

I lingered by his bed, well aware that I wouldn't be sleeping for a while now. For the next few hours, I would have to follow the hospital's strict needle stick protocol. I would sit in our emergency room as a patient, my fellow interns keeping their distance. I would be told to start azidothymidine, a medication that might help prevent me from getting infected, but which could also have difficult side effects. I would need to get blood drawn tonight, in six months, and again in one year before I could be sure that I hadn't acquired the virus. I 
reassured myself that the odds of my infection were extremely small, but I still felt something new and troubling. It was a reality that had been all around me in the hospital - the fear of illness, disability, death. Looking over at Mr. Lee, I realized that he had repeatedly and unknowingly shown me how he confronted what was for me a new experience...mortality and the gnawing fear associated with it.

In the thirty years since I met Mr. Lee, I have often felt his presence. He was by my side when I treated patients facing terminal illness, as I tried to convey his calm acceptance of inevitable death. When I dealt with my own serious illness three years ago, I was comforted by Mr. Lee's example of a well-lived life: a doting partner, strong friendships, and a body of work that would survive him. And when residents in my program were redeployed last year to battle a different virus with even more unknowns, he was with me once more. I told the young doctors his story in response to the fear they described in their own patients and experienced themselves. As physicians, we learn from a variety of mentors, but some of the best-like Mr. Lee - are unforeseen. They are often unaware of the important lessons they teach us.

\section{Declarations}

Disclosures The author states that there is no conflict of interest.

Publisher's Note Springer Nature remains neutral with regard to jurisdictional claims in published maps and institutional affiliations. 